\title{
Komunikasi Kepimpinan Mahathir Mohamad dari Perspektif Agama Hindu
}

\author{
S. MAARTANDAN SUPPIAH \\ Universiti Tunku Abdul Rahman \\ MOHD. KHAIRIE AHMAD \\ Universiti Utara Malaysia \\ HERAN NIRUBAGUNASEKARAN \\ UOW Malaysia KDU Penang University College
}

\begin{abstract}
ABSTRAK
Penyelidikan kualitatif ini bermatlamat untuk meneroka pengaruh komunikasi kepimpinan Mahathir Mohamad dari sudut pandangan budaya masyarakat India di Malaysia. Mahathir dianggap sebagai seorang pemimpin yang hanya memberi tumpuan kepada pembangunan masyarakat Melayu atau masyarakat majoriti yang diwakilinya sehingga beliau dilabel sebagai ultra Melayu. Menariknya, walaupun Mahathir Mohamad dikatakan mengetepikan masyarakat bukan bumiputera khususnya masyarakat India, tetapi masyarakat India merekodkan pembangunan atau perubahan yang baik dalam pelbagai bidang. Dalam pada itu, penyelidikan ini mengandaikan bahawa kemahiran komunikasi kepimpinan Mahathir Mohamad mempengaruhi masyarakat India ke arah pembangunan di Malaysia. Budaya masyarakat India yang ditunjangi oleh kepercayaan Hinduisme dipercayai menjadi nilai asas dalam proses komunikasi kepimpinan Mahathir Mohamad dan masyarakat Hindu di Malaysia. Maka, penyelidikan ini membincangkan tentang komunikasi kepimpinan Tun Mahathir Mohamad dari perspektif budaya India, khususnya dari perspektif agama Hindu. Kaedah temubual mendalam digunakan untuk mengumpul data. Seramai 23 informan telah ditemu bual untuk mengumpul pandangan mereka tentang pimpinan Mahathir Mohamad. Informan penyelidikan dipilih melalui teknik persampelan bertujuan yang terdiri daripada ahli politik berbangsa India, ahli badan bukan kerajaan, para akademik, ahli perniagaan dan masyarakat biasa. Data dianalisa menggunakan kaedah analisis tematik dan tiga tema telah terbentuk iaitu definisi komunikasi kepimpinan, ciri-ciri komunikasi kepimpinan yang berkesan dan fungsi komunikasi kepimpinan. Hasil penyelidikan menunjukkan bahawa agama Hindu mempengaruhi persepsi masyarakat Hindu terhadap komunikasi kepimpinan Mahathir. Penyelidikan ini menyumbang kepada pembentukan dimensi baharu iaitu penyelidikan komunikasi kepimpinan dalam konteks budaya masyarakat India.
\end{abstract}

Kata kunci: Komunikasi politik, budaya India, perubahan sosial, masyarakat India, kepimpinan.

\section{Leadership Communication of Mahathir Mohamad from the perspective of Hinduism}

\section{ABSTRACT}

This exploratory study aims to investigate the influence of leadership communication of Mahathir Mohamad from the Malaysia Hindus perspective. Although Mahathir Mohamad has been labelled as ultra-Malay who merely focused on the development of Malay community (majority community), 
Malaysian Indians recorded positive social change under the leadership of Mahathir Mohamad. This research assume that the leadership communication skill of Mahathir has influenced the Malaysian Indians towards social change. Indian culture was perceived to be mediating the leadership communication process between Mahathir and Malaysian Hindus. The in-depth interview method was utilized in order to gain insight into the influence of Mahathir leadership communication from the Hinduism perspective. Data were collected through a series of intensive interviews with 23 research informants. The informants of the study were selected based on purposive sampling and they include Indian political leader, non-governmental organisations, academics, businessmen, and ordinary members. Based on the findings, a total of three themes; definition of leadership communication, the characteristics of effective leadership communication, and the functions of leadership communication were identified from the thematic analysis using NVivo (qualitative software). From the thematic analysis done, this study contributes to a new dimension of leadership communication study from the Indian cultural context. The present study found that Hinduism influences the perception of the Malaysian Hindus towards the leadership communication of Mahathir Mohamad.

Keywords: Political communication, Indian culture, social change, community, leadership.

\section{PENGENALAN}

Menurut Bass dan Stogdill (1990), kepimpinan merujuk kepada proses komunikasi antara individu yang melibatkan aspek seperti pengurusan situasi, persepsi dan harapan masyarakat yang boleh membawa kepada arus perubahan sosial. Definisi kepimpinan Bass dan Stogdill (1990) menunjukkan bahawa terdapat tiga komponen utama komunikasi kepimpinan iaitu pemimpin, pengikut, dan proses komunikasi antara mereka (Dansereau, Yammarino, \& Markham, 1995). Selaras dengan idea tersebut, Cundiff dan Komarraju (2008) menerangkan bahawa komunikasi kepimpinan ialah proses mempengaruhi sikap dan tingkah laku manusia khususnya persepsi dan keinginan mereka, dan idea ini disokong oleh ramai penyelidik komunikasi kepimpinan (Boatwright \& Forrest, 2000; Kellett, Humphrey, \& Sleeth, 2002; Czech \& Forward, 2010). Ini menunjukkan bahawa kemahiran komunikasi kepimpinan seorang pemimpin dapat mempengaruhi pengikutnya ke arah perubahan sosial.

Banyak penyelidikan yang telah dijalankan untuk menganalisis andaian teori-teori kepimpinan tetapi kebanyakannya memberi tumpuan kepada konteks negara barat atau masyarakat mono-etnik (House \& Aditya, 1997). Walau bagaimanapun, penyelidikan komunikasi antara budaya membuktikan bahawa bukan semua teori tersebut sesuai untuk diaplikasi dalam semua konteks budaya di dunia, khususnya dalam konteks pelbagai budaya (Hofstede, 2001; Smith \& Peterson, 2002). Terdapat penyelidikan yang membuktikan bahawa gaya kepimpinan yang berbeza memberi impak yang berbeza dalam konteks budaya yang berbeza (Smith \& Peterson, 2002). Namun, tidak banyak penyelidikan yang memberi fokus terhadap komunikasi kepimpinan dari sudut agama dan kepercayaan, terutamanya komunikasi kepimpinan antara kaum Melayu dan India di Malaysia (Lynn-Sze, Yusof \& Ahmad, 2014; Lynn-Sze, \& Ahmad, 2017; Suppiah, Ahmad, \& Nirubagunasekaran, 2018; Suppiah, Ahmad, Yusof, \& Velloo, 2019). Maka, penyelidikan tentang komunikasi kepimpinan Mahathir Mohamad daripada perspektif agama Hindu adalah penting kerana penyelidikan ini dapat memberi satu dimensi baru dalam penyelidikan komunikasi kepimpinan khususnya dari perspektif budaya India. 
Tidak dapat dinafikan bahawa walaupun terdapat banyak isu yang berkaitan masyarakat India timbul di bawah kepimpinan Mahathir, namun masyarakat India di Malaysia telah menunjukkan perubahan sosial dalam pelbagai bidang. Dalam konteks kajian ini, budaya kepimpinan yang difokuskan ialah budaya Hindu, namun kepimpinan tranformasi yang dilakukan oleh Mahathir Mohamad ialah budaya Islam. Dalam pada itu, kajian ini meneroka keunikkan aspek ini yang membolehkan komunikasi kepimpinan Mahathir Mohamad membawa perubahan sosial dalam kalangan masyarakat Hindu Malaysia. Kedua, sensitiviti budaya dalam kalangan masyarakat bukan Islam terhadap masyarakat Islam juga bertambah baik ketika beliau menjadi Perdana Menteri yang ke-empat (Saad, 2012). Keadaan ini dapat dijelaskan melalui teori komunikasi kepimpinan seperti teori kepimpinan transformasional yang membincangkan bahawa pemimpin yang mempunyai pengetahuan yang mendalam mengenai budaya pengikutnya dapat menggalakkan pengikutnya ke arah pembangunan atau perubahan sosial (Burns, 1978) dan ini menunjukkan bahawa kepimpinan transformasional dipengaruhi oleh budaya (Kanungo \& Misra, 2004). Singh dan Bhandarker (1990) juga menjelaskan bahawa seorang pemimpin dapat membawa pembangunan dalam kalangan pengikutnya jika pemimpin tersebut mengenali budaya pengikutnya. Walau bagaimanapun, teori kepimpinan transformasional tidak diterokai sepenuhnya dalam konteks budaya masyarakat yang berbilang kaum dan bangsa. Malahan, teori kepimpinan transformasional lebih cenderung mengkaji masyarakat sebagai monoethnik (Smith \& Peterson, 2002).

Oleh itu, penyelidikan ini bertujuan meneroka konsep komunikasi kepimpinan Mahathir Mohamad dari perspektif budaya Hindu Malaysia. Tambahan pula, penyelidikan yang menganalisis komunikasi kepimpinan Mahathir Mohamad dari perspektif budaya India amat terhad (Muniapan, 2006). Oleh itu, penyelidikan ini diharapkan dapat mengisi jurang tersebut dengan meneroka komunikasi kepimpinan Mahathir Mohamad dari perspektif budaya (agama) India. Penyelidikan ini sememangnya dapat memperkaya dan menyumbang kepada pengetahuan komunikasi kepimpinan berdasarkan agama Hindu (falsafah agama Hindu).

Penyelidikan semasa mendapati bahawa agama Hindu memberikan pemahaman yang jelas tentang pembentukan pemikiran individu khususnya melalui falsafah Vedanta. Falsafah ini menjelaskan bahawa individu berlainan mempunyai ciri-ciri pemikiran tersendiri yang akan mempengaruhi sikap dan tingkah laku mereka dalam kehidupan seharian (Bhagwad Gita, 3: 2021).

\section{Kepimpinan Komunikasi dan Budaya India}

\section{SOROTAN KAJIAN}

Menurut Gardenswartz, Rowe, Digh, dan Bennett (2003) definisi budaya sentiasa diperbaharui dan bergantung kepada pendapat seseorang individu. Idea ini selaras dengan konsep komunikasi kepimpinan yang merujuk kepada proses pembentukan makna. Oleh itu, budaya dan komunikasi kepimpinan adalah saling berkaitan, di mana seorang pemimpin mengetahui dan memahami sesuatu budaya and kemudiannya menyesuaikan diri dengan budaya tersebut (Schein, 1985). Menurut Singh dan Krishnan (2007) kepimpinan diklasifikasikan sebagai satu fenomena sosial, oleh itu, kepimpinan adalah relevan untuk dikaji dalam konteks budaya. Mereka juga berpendapat bahawa pemimpin perlu peka terhadap latar belakang budaya pengikut mereka 
untuk memastikan keperluan dan kehendak para pengikut dapat dipenuhi (Singh \& Krishnan, 2007).

Selari dengan hujah ini, Bass (1997) juga menyatakan bahawa tingkah laku yang berbeza dapat dipamerkan oleh para pemimpin dalam budaya yang berbeza apabila mempunyai pemahaman antara budaya yang mendalam. Oleh itu, sangat penting bagi pemimpin, terutamanya untuk pemimpin transformasi untuk mengadaptasi tingkah laku mereka mengikut konteks budaya yang berbeza. Bersikap sensitif terhadap budaya lain adalah komponen komunikasi kepimpinan yang sangat penting, khususnya untuk pemimpin transformasi. Hofstede (1980) menyatakan bahawa budaya terdiri daripada beberapa aspek dan lapisan di mana "pengaturcaraan kolektif minda manusia" berlaku (Hofstede, 1980, hlm. 43).

Selain itu, Ergeneli, Gohar, dan Temirbekova (2007) mengkaji hubungan antara kepimpinan transformasi dan dimensi budaya yang diperkenalkan Hofstede. Penemuan mereka memperkuat lagi penyelidikan Bass dan Avolio (1994) yang menyimpulkan bahawa kepimpinan transformasi sesuai diaplikasi dalam pelbagai budaya. Selain itu, penyelidik komunikasi kepimpinan juga berpendapat bahawa pemahaman yang baik tentang budaya pengikut adalah sangat penting bagi seorang pemimpin untuk mewujudkan hubungan yang erat dan meraih sokongan padu pengikut (Krishnan, 2002). Pemimpin juga perlu membentuk visi untuk para pengikutnya yang dapat dijadikan sebagai panduan, yang bermaksud pemimpin mesti mampu menggaris hala tuju yang jelas untuk pengikutnya (Bass, 1990). Oleh itu, penyelidikan ini bermatlamat mencerminkan kualiti kepimpinan Mahathir Mohamad sebagai seorang kepimpinan transformasi; beliau memperkenalkan dan melaksanakan visi serta menunjukkan komitmen dan usaha yang tinggi dalam usaha transformasi rakyat Malaysia, termasuklah kaum India. Sehubungan dengan itu, Mahathir Mohamad dilihat sebagai seorang pemimpin yang sensitif terhadap budaya pengikutnya, termasuk kaum India, dan membawa perubahan sosial dalam masyarakat India di Malaysia.

Penyelidikan juga telah dijalankan oleh Jung dan Avolio (1999) untuk membandingkan gaya kepimpinan transformasi dan transaksional dalam konteks budaya. Penyelidikan terbaru yang berkaitan dengan budaya dan kepimpinan dijalankan oleh Pauliene (2012) mendapati bahawa nilai kebudayaan pengikut dan pemimpin mempengaruhi proses komunikasi kepimpinan. Penyelidik juga telah mengkaji hubungan antara jenis budaya dan keberkesanan kepimpinan. Pemimpin transformasi dianggap sebagai penyelaras yang menggalakkan persekitaran yang harmoni untuk pengikutnya (Pauliene, 2012). Ini jelas menunjukkan bahawa para pemimpin yang mempunyai pengetahuan tentang budaya pengikut dapat menyumbang kepada komunikasi kepimpinan yang berkesan dan perubahan sosial.

Penyelidikan yang dijalankan oleh Markus dan Kitayana (1991) juga mendapati bahawa faktor budaya merupakan asas dalam proses kepimpinan. Prototaip dan konsepsi kepimpinan adalah berbeza dari satu budaya ke budaya yang lain (Bass, 1990), dan ini membawa implikasi berbeza dalam konteks budaya yang berbeza (Chemers \& Ayman, 1993). Ini bermakna seorang pemimpin perlu memahami dan memenuhi keperluan budaya pengikutnya untuk menggalakkan para pengikutnya ke arah perubahan sosial dan matlamat bersama. Interaksi pemimpin dan pengikut mempengaruhi proses komunikasi mereka, terutama di negara yang berbilang kaum dan etnik seperti Malaysia. Oleh itu, bahagian seterusnya akan membincangkan budaya India dan hubungannya dengan komunikasi kepimpinan. 
Sejak penerbitan buku Hofstede pada tahun 1980, penyelidikan tentang pengaruh budaya terhadap sikap dan tingkah laku individu mendapat perhatian daripada pelbagai penyelidik (Mohd Yusoff, Roselina, \& Syed Azizi, 2002). Hofstede telah mengenal pasti beberapa dimensi budaya dan terus mereplikasi penyelidikannya di banyak negara sehingga tahun 2010 melalui 76 penyelidikan mengenai topik ini (Hofstede \& Minkov, 2010). Namun begitu, penyelidikan Hofstede boleh dipertikaikan kerana beliau telah mengkategori Malaysia sebagai sebuah masyarakat mono-etnik dengan mengabaikan aspek multi-etnik masyarakat majmuk (Hofstede, 1991). Sehubungan dengan itu, beberapa penyelidikan susulan dijalankan oleh penyelidik tempatan untuk membuktikan bahawa setiap kumpulan etnik di Malaysia adalah unik dan berbeza dan penyelidikan Hostfede tidak menjelaskan masyarakat Malaysia dari sudut budaya secara mendalam (Mohd Yusof et al., 2002).

Program penyelidikan 10 tahun (Global Leadership and Organizational Behaviour Effectiveness Research Program, GLOBE) telah mengkategorikan Malaysia sebagai negara monoetnik dengan mengabaikan aspek pelbagai budaya di negara ini. Penyelidikan GLOBE mengandaikan bahawa tidak ada hubungan yang signifikan antara kumpulan etnik yang berlainan di Malaysia (Kennedy, 2002). Graen (2006) mengkritik penyelidikan GLOBE kerana penyelidikan tersebut tidak mempertimbangkan unsur kepelbagaian budaya masyarakat majmuk di Malaysia. Oleh itu, Triandis dan Brislin (1984) menegaskan kepentingan penyelidikan dalam konteks budaya untuk mengembangkan teori dan mencari pengertian yang mendalam. Oleh itu, Dahlia (2008) mencadangkan pengkaji masa depan untuk menjalankan penyelidikan untuk memahami unsur kepelbagaian budaya negara Malaysia.

Wibbeke (2009) berpendapat bahawa seorang pemimpin yang mempunyai kemahiran komunikasi antara budaya yang baik akan mempunyai pengetahuan tentang impak sosial terhadap orang lain. Oleh itu, penyelidikan ini melihat budaya (agama) sebagai unsur penting dalam komunikasi kepimpinan antara pemimpin dan pengikut dari pelbagai kumpulan etnik. Oleh itu, untuk berkomunikasi dengan berkesan, pemimpin perlu memahami budaya pengikutnya kerana budaya mempunyai pengaruh yang besar dalam kehidupan manusia (House \& Aditya, 1997). Elemen ini menjadikan komunikasi kepimpinan lebih dinamik dan penyelidikan ini menjangka terdapat "budaya bersama" atau shared culture antara kaum India (beragama Hindu) dengan kaum Melayu, khususnya Mahathir Mohamad yang membolehkan masyarakat Hindu Malaysia menerima kepimpinan Mahathir Mohamad.

\section{Agama Hindu Sebagai Pengantara Kepimpinan Transformasi dan Perubahan Sosial}

Budaya menyumbang kepada keberkesanan komunikasi kepimpinan kerana pengaruh kepimpinan bergantung pada pemahaman seorang pemimpin terhadap keperluan dan kehendak pengikutnya (House \& Aditya, 1997). Menurut Bass (1997), walaupun kepimpinan transformasional adalah universal, namun seorang pemimpin perlu bertindak dan menyesuaikan diri mengikut budaya. Selain itu, penyelidikan juga membuktikan bahawa pembentukan dan artikulasi visi merupakan salah satu komponen asas kepimpinan transformasi yang berkaitan rapat dengan budaya dan sebagai contoh, perkara ini dilihat melalui kemahiran pidato pemimpin di Amerika Syarikat dan perkhidmatan masyarakat oleh Mother Teresa di India (Smith \& Peterson, 2002). 
Bass dan Steidlmeier (1999) mengakui bahawa kepimpinan transformasi adalah berkesan kerana menggabungkan komponen budaya yang merupakan asas kepimpinan komunikasi. Penyelidik seperti Kanungo dan Misra (2004) berpendapat bahawa kepimpinan transformasi adalah penting di negara-negara membangun seperti India. Ini adalah kerana pemimpin transformasi dapat memenuhi keperluan pengikut dan merangsang mereka ke arah perubahan sosial dengan mengenal pasti budaya para pengikutnya. Selaras dengan idea tersebut, Singh dan Bhandarker (1990) menyatakan bahawa perubahan sosial dalam masyarakat hanya akan berlaku apabila seorang pemimpin peka terhadap sensitiviti budaya masyarakat.

Dari segi perkaitan budaya India dan kepimpinan transformasi, Krishnan (2001) menyatakan bahawa budaya India menyumbang kepada pembangunan kepimpinan transformasional. Tamadun India adalah salah satu tamadun tertua di dunia yang telah wujud lebih dari 5000 tahun. Contohnya, banyak karya sastera klasik seperti "Valmiki Ramayana", "Mahabharata" (termasuk Bhagavad-Gita), memberikan pengajaran kepimpinan yang relevan dalam konteks moden. Selain itu, para penyelidik juga menjalankan banyak penyelidikan untuk menjelaskan hubungan antara budaya dan kepimpinan (Leslie \& Van Velsor, 1998).

Di samping itu, para ilmuan juga menekankan tentang keperluan mengkaji agama Hindu dalam konteks pengurusan moden kini (Chinmayananda, 2003). Selaras dengan idea ini, satu penyelidikan telah dijalankan oleh Muniapan (2007) untuk mengkaji hubungan antara kepimpinan transformasi dan Valmki Ramayana (kesusasteraan klasik). Oleh itu, penyelidikan ini bertujuan mengaitkan budaya India (falsafah agama Hindu) dengan komunikasi kepimpinan yang menumpukan kepada komunikasi kepimpinan Mahathir Mohamad.

Bhagavad-Gita dianggap sebagai rujukan utama agama Hindu yang memuatkan falsafah Veda (Easwaran, 1985). Falsafah Veda merujuk kepada falsafah, tradisi dan amalan Hindu. Dipercayai bahawa pengetahuan itu diturunkan oleh Tuhan untuk manusia (Mehta, 2012). Ramayana dan Bhagavad-Gita memuatkan perbincangan terperinci mengenai kehidupan manusia, terutama mengenai cara seorang menjalani hidup di dunia. Ramayana dan BhagavadGita mengandungi ajaran moral dan prinsip agama Hindu yang menawarkan banyak pengetahuan kepemimpinan yang relevan dalam konteks moden (diperolehi daripada http://www.rsl.ukans.edu/pkanagar/divine/). Sebagai bukti, kajian yang dilakukan oleh Engardio dan McGregor (2006) menyatakan bahawa terdapat pelbagai pengetahuan kepemimpinan yang terkandung dalam Bhagavad-Gita dan Ramayana dan banyak institusi pengajian perniagaan terkemuka di Amerika Syarikat telah memperkenalkan "kelas penguasaan diri" dengan menggunakan falsafah agama Hindu untuk meningkatkan kemahiran komunikasi kepemimpinan.

Bhagavad-Gita merupakan teks tertua di dunia yang terdiri daripada banyak pengetahuan kepemimpinan. Pada mulanya, Bhagavad-Gita pada mulanya ditulis dalam bahasa Sanskrit dan pertama kali diterjemahkan pada tahun 1785. Dipercayai bahawa teks tersebut diajar dan disampaikan secara lisan sejak 3100 SM (Hee, 2007). Ringkasnya, Bhagavad-Gita memuatkan teks yang melibatkan perbincangan antara putera, Arjuna dan Dewa Krishna. Perbincangan tersebut berlaku di medan perang antara Pandav, yang merupakan milik Arjuna dan Kaurava, yang menjadi milik pembangkang. Di medan perang, Arjuna menolak untuk berperang dengan Kaurava kerana mereka adalah kerabatnya dan bertanya kepada Dewa Krishna tentang keperluan perang tersebut. Dewa Krishna menjelaskan keperluan perang tersebut dalam memainkan peranannya untuk melindungi Dharma (kebenaran) (Hee, 2007). 
Bhagavad-Gita juga membincangkan bahawa sifat manusia (Gunas) boleh dibahagikan kepada tiga sifat utama; "Sattva", "rajas" dan "tamas" (Chinmayananda, 2003). Menurut Bhagavad-Gita, persilangan ketiga-tiga sifat ini (Gunas) menyumbang kepada pembentukan mental seorang yang mempengaruhi sikap dan tingkah laku individu tersebut. Secara umum, "sattva guna" merujuk kepada sifat individu yang mementingkan keharmonian dan kesejahteraan orang dan tidak mementingkan diri sendiri. Mereka peka terhadap keperluan orang lain dan berusaha mencapai tujuan bersama. Rajas merujuk kepada sifat individu yang hanya berfikir untuk diri sendiri yang hanya bertujuan untuk menjaga ego, kemasyhuran, nama dan kekuatan. Tamas pula merujuk kepada sifat individu yang didorong oleh kepentingan peribadi mereka, dan sanggup mengorbankan orang lain untuk tujuan diri sendiri. "Sattva guna" yang mencerminkan seorang pemimpin yang dipandang tinggi dan beretika kerana memberi inspirasi kepada pengikut yang dapat menyumbang kepada pembentukan persepsi positif dalam kalangan pengikut. Menariknya, menurut Kejriwal dan Krishnan (2004), "sattva guna" dapat digunakan untuk meningkatkan kepemimpinan transformasional dan membawa perubahan. Dalam kata lain, kajian tersebut membuktikan bahawa seorang individu atau pemimpin harus memiliki "sattva guna" untuk mempengaruhi pengikut ke arah perubahan sosial.

Ciri kepemimpinan transformasional dalam agama Hindu dan perkaitannya dengan komunikasi kepimpinan Mahathir Mohamad

Ciri kepemimpinan transformasional jelas dalam karya klasik Hindu seperti dalam Ramayana, Bhagavad-Gita dan Bala Kanda. Perlu diperhatikan bahawa ciri-ciri komunikasi kepemimpinan transformasional jelas dalam epik Ramayana melalui watak utama epik, Sri Rama sebelum pembentukan model kepemimpinan transformasional oleh Burns (1978) dan Bass dan Avolio (1994). Sebagai bukti, dalam buku Bala Kanda, watak Sri Rama diklasifikasikan sebagai cerdas, rasional, prihatin terhadap kesejahteraan orang lain, melindungi orang, pengamal prinsip agama yang benar, bertekad, berani, dan disayangi oleh semua orang. Ciri-ciri ini telah menjadikan orang-orang di Ayodhya untuk mengagumi dan mendapat inspirasi daripada pemimpin mereka, Sri Rama (Muniapan, 2007). Ciri-ciri yang diketengahkan sesuai dengan perbincangan mengenai ciri-ciri seorang pemimpin transformasi. Tichy dan Devanna (1990) yang melakukan kajian luas mengenai kepemimpinan transformasional telah menyenaraikan tujuh ciri pemimpin transformasional.

Pertama, pemimpin transformasional adalah agen perubahan yang bertujuan untuk membawa masyarakat dan negara ke arah perubahan sosial dengan merangsang perubahan dalam sikap dan tingkah laku pengikut. Sebagai contoh, dalam Ramayana, Sugriva mengubah sikapnya setelah bertemu dengan Sri Rama. Dalam keadaan lain, Sri Rama juga turut menyumbang kepada perubahan kekeluargaan Lanka sebelum perang melawan Ravana.

Kedua, pemimpin transformasi adalah orang yang berani. Mereka adalah pengambil risiko dan memastikan bahawa visi dan tujuan mereka tercapai. Dalam Ramayana, Sri Rama menggambarkan watak mengambil risiko apabila beliau menepati janji yang dibuat kepada ayahnya. Walaupun beliau dipujuk oleh saudara-mara untuk mengubah pendiriannya, beliau sangat tegas dan berani terhadap keputusannya. 
Ketiga, pemimpin transformasi mempercayai orang lain atau pengikutnya. Pemimpin transformasi sentiasa mempraktikkan pendekatan positif dan percaya bahawa ada banyak potensi pada orang yang memerlukan motivasi dan dorongan untuk ditonjolkan. Dalam Ramayana, Sri Rama percaya bahawa Hanuman akan berjaya mencari isterinya, Sita dan beliau dengan yakin memberikan cincinnya kepada Hanuman dan memintanya untuk memberikannya kepada Sita ketika bertemu dengannya.

Seterusnya, pemimpin transformasi didorong oleh nilai-nilai murni. Terdapat nilai-nilai murni yang memancu tindakan pemimpin transformasi. Dalam Ramayana, Sri Rama tidak pernah memungkiri janji sepanjang pemerintahannya. Beliau mengatakan kepada Sita bahawa beliau bersedia untuk mengorbankan nyawanya untuk melindungi guru-guru yang tinggal di hutan, Dandaka kerana beliau berjanji kepada mereka.

Pemimpin transformasional adalah pelajar sepanjang hayat yang melakukan pembelajaran dan pengembangan kendiri secara berterusan. Mereka memandang kesilapan sebagai pengalaman. Dalam Ramayana, Sri Rama menerima pelajaran daripada guru seperti Vasistha Muni, Visvamitra Muni, Bharadvaja Muni, Jabali Muni, Atri Muni, dan lain-lain sejak kecil sekali gus menjadi pemimpin Ayodhya yang bijak dan dihormati.

Pemimpin transformasional juga mempunyai kemampuan untuk menangani kerumitan, kekaburan dan ketidakpastian. Dalam kata lain, perkara ini merujuk kepada kemahiran menyelesaikan masalah. Dalam Bhagavad-Gita 3.21, Sri Krishna memberitahu Arjuna bahawa seorang pemimpin harus menjadi suri teladan bagi pengikutnya (Muniapan, 2007). Dalam Ramayana, Sri Rama mengambil keputusan tegas untuk menghantar Sita (isteri Sri Rama) dari Ayodhya. Walaupun itu adalah keputusan yang tegas, Sri Rama membuat keputusan dengan mengenepikan kepentingan peribadinya untuk menegakkan kehormatan kerajaannya.

Pemimpin transformasional adalah berwawasan. Sebagai contoh, Sri Rama memperkenalkan visi untuk Ayodhya dan menyampaikannya kepada orang ramai. Ringkasnya, dapat disimpulkan bahawa idea kepemimpinan transformasional dibincangkan dalam budaya India. Karya klasik Hindu memberikan idea tentang ciri-ciri pemimpin yang mulia dan komunikasi kepemimpinan yang secara tidak langsung mewujudkan persepsi dalam pemikiran masyarakat Hindu mengenai komunikasi kepemimpinan yang baik. Di samping itu, kajian ini menyiasat komunikasi kepemimpinan Mahathir yang berkaitan dengan perbincangan komunikasi kepemimpinan yang terdapat dalam karya klasik Hindu. Oleh itu, kajian ini dianggap penting kerana dapat memberikan dimensi baru kepada komunikasi kepemimpinan dari perspektif agama Hindu dan konteks hubungan masyarakat majoriti-minoriti (Melayu-India).

Kajian ini menyimpulkan bahawa komunikasi kepemimpinan Mahathir Mohamad dapat dianalisis melalui tujuh ciri pemimpin transformasi yang disenaraikan oleh Tichy dan Devanna (1990). Pertama, pemimpin transformasi adalah agen perubahan. Situasi ini boleh dikaitkan dengan Mahathir yang mempengaruhi perubahan kepemimpinan Tunku Abdul Rahman. Mahathir dianggap kritis terhadap kepemimpinan Tunku Abdul Rahman dan polisi yang dilaksanakan oleh Tunku Abdul Rahman. Contoh lain yang dapat dilihat ialah kebijaksanaan Mahathir yang memberi tumpuan terhadap sektor perindustrian daripada sektor pertanian untuk membangunkan masyarakat dan negara yang dilihat sebagai usaha positif oleh masyarakat Hindu. 
Kedua, pemimpin transformasi dianggap sebagai orang yang berani. Mahathir dianggap sebagai seorang pemimpin yang tekun dalam melaksanakan dasar-dasarnya untuk kebaikan rakyat dan negara. Sebagai contoh, untuk mendapatkan sokongan orang ramai, beliau menjelaskan alasan atau rasional dasar-dasarnya kepada rakyat dan negara. Secara khusus, semasa krisis ekonomi pada tahun 1998, Mahathir mengambil keputusan yang bijak dengan menstabilkan mata wang Malaysia (Wain, 2012).

Ketiga, pemimpin transformasi dapat digambarkan sebagai orang yang percaya akan orang lain. Seorang pemimpin transformasi percaya bahawa rakyat mampu melaksanakan tugas yang diberikan. Oleh itu, Mahathir memperkasa masyarakat melalui visi yang diperkenalkannya. Beliau menyeru masyarakat supaya bekerja keras dalam mencapai visi yang diperkenalkannya. Sebagai contoh, beliau menekankan kod etika penjawat awam dengan membuat pindaan pada Perintah Am. Garis panduan kod etika baru lebih menekankan pada nilai moral dan sikap penjawat awam yang merangkumi kebersihan, kecekapan, dan kepercayaan. Kod etika berfungsi sebagai panduan bagi pegawai kerajaan untuk memastikan kecekapan sektor kerajaan (Rais, 1988, dalam Ahmad Atory, 1997).

Seterusnya, pemimpin transformasi memiliki nilai-nilai murni. Selaras dengan idea itu, Mahathir dianggap sebagai pemimpin yang menunaikan janji. Sebagai contoh, Mahathir berjanji membina infrastruktur seperti Lapangan Terbang Antarabangsa Kuala Lumpur (KLIA), Pusat Bandaraya Kuala Lumpur (KLCC) dan Putrajaya sebagai sebahagian daripada proses pemodenan dan beliau menunaikan janji tersebut. Beliau juga menunjukkan komitmen yang tinggi untuk membangun masyarakat dan negara.

Pemimpin transformasional juga mempunyai kemampuan untuk menangani ketidakpastian. Mahathir dianggap sebagai penyelesai masalah. Dasar dan visinya bertujuan untuk menyelesaikan masalah yang berkaitan dengan masyarakat dan negara. Sebagai contoh, Mahathir telah memperkenalkan Dasar Pembangunan Nasional untuk menangani masalah sosioekonomi, khususnya untuk mengatasi ketidakseimbangan ekonomi dan sosial antara kaum.

Akhir sekali ialah berwawasan. Mahathir telah memperkenalkan visi untuk rakyat dan negara, seperti Wawasan 2020. Mahathir telah merangka visi yang jelas untuk menjadikan Malaysia menjadi sebagai sebuah negara maju. Beliau juga telah membentuk garis panduan dalam merealisasikan visi tersebut.

\section{METODOLOGI}

Penyelidikan ini menggunakan kaedah kualitatif untuk mengkaji persepsi masyarakat Hindu terhadap komunikasi kepimpinan Mahathir Mohamad dari perspektif budaya India (agama Hindu). Bagi mendapatkan perspektif holistik mengenai komunikasi kepimpinan dari perspektif budaya India (agama Hindu), 23 informan yang beragama Hindu telah dipilih dengan menggunakan persampelan purposive; dan temu bual mendalam berbentuk semi-struktur digunakan berdasarkan cadangan Patton (2002). Informan terdiri daripada pemimpin politik India, badan bukan kerajaan, ahli perniagaan, serta orang awam. Analisis tematik digunakan untuk mengenal pasti, menganalisis dan membina tema bagi data yang dikumpul. Tiga peringkat analisis tematik yang merupakan pengekodan data, pembentukan tema dan pembinaan tema analitikal telah digunakan dalam penyelidikan ini (Thomas \& Harden, 2008). 
Kaedah fenomenologi Colaizzi (1978) digunakan dalam menganalisis transkrip temu bual mendalam. Dalam kaedah ini, semua transkrip bertulis dibaca beberapa kali. Untuk setiap transkrip, frasa atau ayat penting yang berkaitan dengan maklum balas masyarakat Hindu Malaysia mengenai komunikasi kepemimpinan Mahathir dikenal pasti. Kemudian, makna dirumuskan berdasarkan pernyataan dan frasa. Makna yang dirumuskan dikategorikan kepada beberapa tema dan kemudian hasilnya disatukan. Setelah tema dibentuk, penyelidik meminta beberapa informan untuk memberi pendapat terhadap penemuan tersebut.

\section{PENEMUAN DAN PERBINCANGAN}

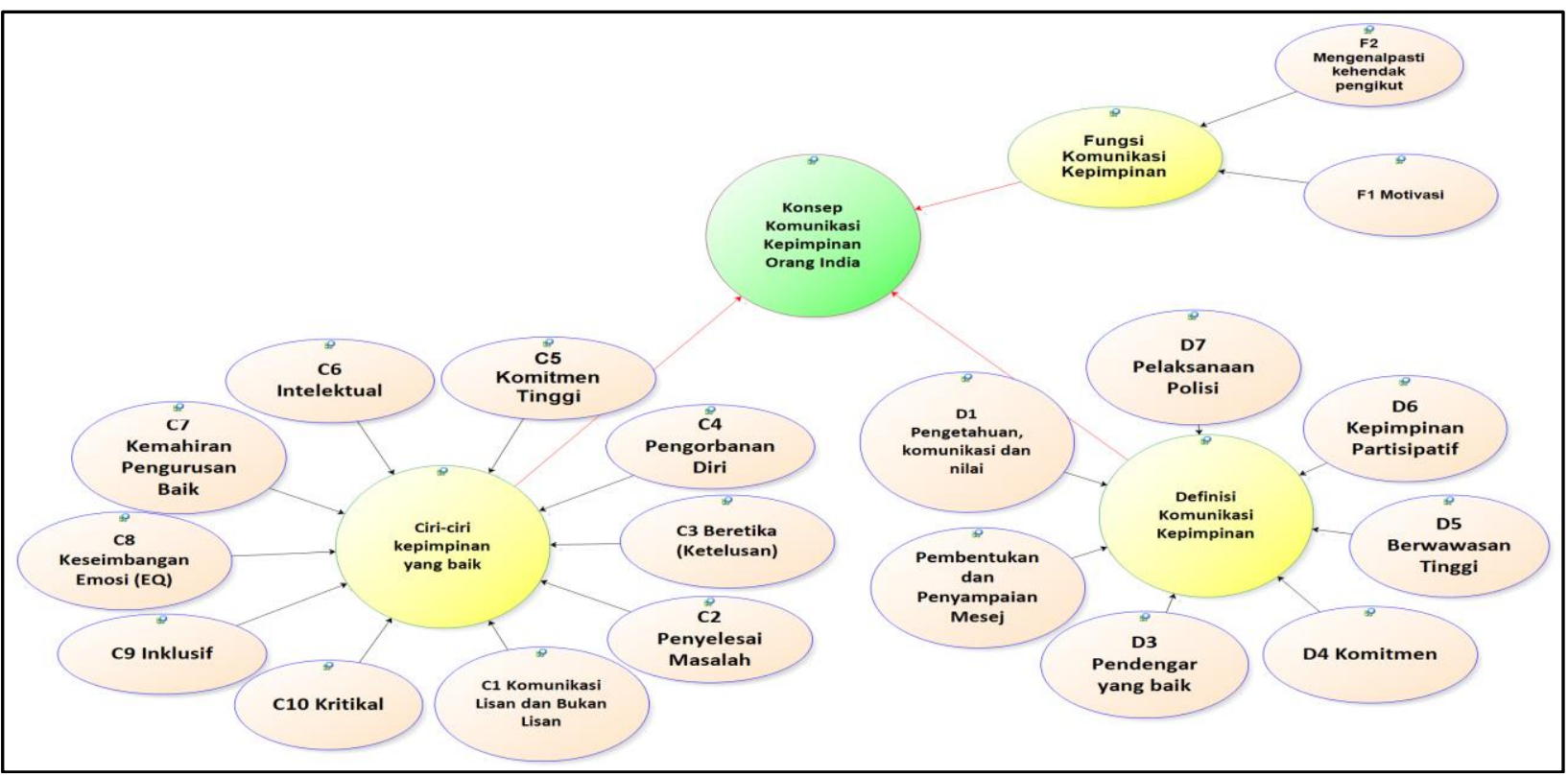

Rajah 1: Konsep komunikasi kepimpinan India

Bahagian ini membincangkan keputusan analisis data yang diperoleh daripada data yang dikumpulkan daripada 23 informan. Matlamat penyelidikan ini adalah untuk mengkaji maklum balas masyarakat Hindu Malaysia terhadap komunikasi kepimpinan Mahathir Mohamad dari perspektif agama Hindu. Dengan menggunakan teknik analisis tematik, beberapa tema utama dibentuk dan dipersembahkan berdasarkan teori kepimpinan transformasional. Data telah dianalisis dengan menggunakan perisian NVivo dan rajah di atas telah dibina berdasarkan hasil analisa tersebut. Rajah 1 menunjukkan bahawa terdapat tiga tema yang dapat menjelaskan konsep komunikasi kepimpinan menurut masyarakat Hindu di Malaysia.

\section{Definisi Masyarakat Hindu Terhadap Komunikasi Kepimpinan}

Analisis tematik menunjukkan bahawa definisi komunikasi kepemimpinan merujuk kepada beberapa komponen penting iaitu aspek pengetahuan, komunikasi dan nilai; pembentukan dan penyampaian mesej; pendengar yang baik; komitmen; berwawasan tinggi; kepemimpinan partisipatif dan pelaksanaan dasar. 
Informan 3 menjelaskan bahawa komunikasi kepemimpinan sebagai gabungan pengetahuan dan komunikasi yang dapat dijadikan teladan oleh pengikut. Dalam sesi temu bual dengan informan, beliau berkata:

“... Pertama, kepemimpinan adalah gabungan aspek pengetahuan dan nilai yang dipraktikkan oleh pemimpin. Sudah tentu pengetahuan dalam bidang yang anda terlibat adalah penting. Kedua, kemahiran seperti kemahiran perhubungan awam atau kemahiran komunikasi adalah sangat penting dan ketiga, nilai atau pegangan hidup. Sebagai contoh, Einstein adalah salah seorang saintis terhebat pada abad ke-20 kerana pengetahuannya. Ramai orang memandangnya sebagai pemimpin kerana dia cemerlang dalam bidangnya. Contohnya seperti Barack Obama, Presiden Amerika Syarikat ke-44. Beliau belajar di Harvard dan merupakan seorang pengacara yang baik. Namun, apa yang membuatnya menjadi Presiden kulit hitam pertama? Ketika beliau diusulkan sebagai calon Presiden, beliau adalah seorang underdog dibandingkan dengan Hilary Clinton. Cara beliau berkomunikasi dengan orang menjadikannya sebagai Presiden, secara khususnya cara beliau bercakap dan cara beliau menangani media. Ini melibatkan kemahiran lisan dan bahasa badan yang berbeza. Ketiga adalah nilai yang anda pegang. Ini adalah asas komunikasi kepemimpinan, contohnya anda perlulah jauhi rasuah..." (R3).

Selanjutnya, informan 11 dan 21 menekankan dua konsep utama komunikasi kepemimpinan iaitu pembentukan dan penyampaian mesej. Keadaan ini dapat dilihat dalam petikan berikut:

“... Komunikasi kepemimpinan bukan semata-mata merujuk kepada proses penyampaian idea, tetapi juga cara anda menyampaikannya. Apabila anda menyampaikan idea, anda perlulah mengetahui hadirin anda kerana penyampaian yang berbeza diperlukan untuk hadirin yang berbeza..." (R11).

"... Komunikasi kepemimpinan merujuk kepada pelbagai cara berkomunikasi dengan masyarakat atau organisasi yang berkaitan dengan pelbagai bidang termasuk ekonomi, sosial dan pendidikan. Ringkasnya, komunikasi kepimpinan didefinisikan sebagai cara berkomunikasi yang berkesan dengan semua lapisan masyarakat. Komunikasi kepimpinan haruslah bersifat dua hala dan harus menjadi teladan kepada orang ramai..." (R21).

Selain itu, informan 14 juga menegaskan bahawa kemahiran mendengar yang baik adalah komponen penting dalam komunikasi kepimimpinan. Menurut informan, seorang pendengar yang baik dapat memberikan jalan penyelesaian yang terbaik kepada pengikutnya. Dalam pernyataan yang sangat jelas, informan 14 mengatakan bahawa, seorang pemimpin harus menjadi pendengar yang baik. Seorang pemimpin mesti memahami kehendak dan keperluan setiap pengikut. Selain itu, informan 18 menekankan bahawa komunikasi kepemimpinan adalah mengenai proses menunaikan janji pengikut. Informan 18 mengatakan bahawa seorang 
pemimpin yang menjanjikan sesuatu kepada pengikutnya perlu memastikan dia menunaikannya. Sebagai pemimpin, jangan hanya berjanji jika anda tidak dapat melaksanakannya atau menunaikannya.

Informan 1, 2, 13, 16 dan 22 menyatakan bahawa pembentukan dan penyampaian visi adalah salah satu komponen penting komunikasi kepemimpinan. Para informan menekankan kepentingan pembentukan dan penyampaian visi dalam komunikasi kepemimpinan. Pandangan ini jelas dalam petikan berikut:

“... Komunikasi kepemimpinan adalah berkaitan dengan pembentukan dan penyampaian visi dengan berkesan, terutama kepada pengikut. Bagaimana anda dapat berkomunikasi dengan pengikut anda dengan berkesan? Pemimpin perlulah memastikan bahawa semua pengikut mempunyai visi yang sama. Pertama sekali, visi yang dibentuk mesti diterima oleh semua pengikut dan visi yang dibentuk tidak seharusnya bertumpu pada satu kumpulan pengikut tertentu. Apabila kita berbicara mengenai komunikasi kepemimpinan Hitler, beliau mempunyai komunikasi kepemimpinan yang sangat baik. Beliau memiliki sokongan padu orang Jerman, dan dapat meyakinkan orang Jerman, Maka, mereka menurutinya; sama ada kepimpinannya betul atau salah. Jika kita meneliti komunikasi kepimpinannya, kita dapat melihat satu sistem komunikasi..." (R13).

Berdasarkan penemuan penyelidikan ini, masyarakat Hindu telah mengenal pasti tiga idea utama dalam menentukan definisi komunikasi kepimpinan iaitu sikap positif, kemahiran berkomunikasi yang berkesan, dan gaya kepimpinan. Sikap positif, sikap menepati janji dan beretika dilihat sebagai komponen penting dalam komunikasi kepimpinan. Seorang pemimpin perlu memenuhi janji-janjinya kepada rakyat dan negara, dan perlu menjadi pemimpin yang beretika. Penyelidkan yang dijalankan oleh Sinha dan Kaur (1992), jelas mencerminkan ciri-ciri "sattva guna" iaitu ketelusan dan semangat untuk berkhidmat. Oleh itu, kajian ini mendapati bahawa elemen ketelusan yang ditonjolkan oleh informan kajian adalah berkaitan dengan "sattva guna" falsafah Hindu. la mendapati bahawa ketelusan meningkatkan keyakinan pengikut terhadap pemimpin. Kedua, dari segi kemahiran komunikasi yang berkesan, ciri-ciri komunikasi kepimpinan yang dilihat sebagai komunikasi yang efektif adalah pemimpin yang berupaya memperkenal dan menyampaikan visi untuk masyarakat dan negara, menjadi pendengar yang aktif, dan dapat menyampaikan mesej dengan berkesan. Komponen ketiga adalah gaya kepimpinan. Penemuan penyelidikan ini menunjukkan komunikasi kepimpinan melibatkan gaya kepimpinan partisipatif yang menggalakkan penyertaan orang ramai dalam proses komunikasi kepimpinan. Ciri ini juga dapat dikaitkan dengan watak-watak dalam Bhagavad-Gita yang menekankan aspek kesaksaman sosial.

Dalam Bhagavad-Gita, Davis (2014) menyatakan bahawa kelahiran Dewa Krishna mencerminkan kesaksamaan sosial kerana dilahirkan dalam sebuah suku penggembala lembu dan bukan sebagai Brahmana atau Kshatriya. Seperti yang diperlihatkan dalam Bhagavad-Gita, setiap individu harus melaksanakan tugas yang ditentukan dengan menjadi teladan dan berbuat baik kepada orang lain (Bhagavad-Gita, 3: 20-21). Ringkasnya, berdasarkan perspektif agama Hindu, ciri-ciri komunikasi kepemimpinan yang baik terdiri daripada amalan gaya kepemimpinan 
partisipatif, etika yang baik dan komunikasi yang berkesan. Seorang pemimpin dengan ciri-ciri ini dapat memotivasi, memberi inspirasi dan mewujudkan keyakinan dalam kalangan masyarakat terhadap perubahan sosial. Berdasarkan idea yang dibentuk, perbincangan ini didapati relevan dengan falsafah agama Hindu yang ditekankan dalam Bhagavad-Gita supaya pemimpin mendorong pengikutnya untuk memberi maklum balas, menjadi komunikator yang berkesan, berani dan berwawasan, dan beretika.

Definisi komunikasi kepimpinan yang diberikan oleh informan kaum India boleh dikaitkan dengan definisi Barrett (2014) yang membincangkan bahawa komunikasi kepimpinan sebagai proses yang melibatkan pembentukan mesej yang bertujuan untuk mempengaruhi orang melalui kemahiran berkomunikasi yang baik dan mewujudkan hubungan positif bersama pengikut dengan memotivasi dan menjadi inspirasi kepada mereka. Definisi Barrett (2014), mempunyai tiga komponen utama komunikasi kepimpinan yang didapati konsisten dengan definisi yang dilaporkan dalam penyelikan ini; pembentukan dan perkongsian makna (kemahiran komunikasi: penterjemahan visi), mewujudkan hubungan positif (sikap positif: memenuhi janji kepada rakyat) dan mendorong pengikut untuk mencapai matlamat bersama (gaya kepimpinan: kepimpinan partisipatif). Dari sudut pandangan agama Hindu, Bhagavad-Gita telah mengkategorikan individu berdasarkan tiga sifat (Gunas); iaitu 'Sattva', 'Rajas' dan 'Tamas' (Chinmayananda, 1992).

Berdasarkan Bhagavad-Gita, tiga sifat (Gunas) ini menyumbang kepada pembentukan fikiran seorang individu. Secara umumnya, 'Sattva Guna' merujuk kepada sifat-sifat seorang individu yang bekerja untuk kebaikan dan pembangunan masyarakat tanpa mementingkan diri sendiri. Mereka peka terhadap keperluan orang lain dan berusaha ke arah matlamat bersama. 'Rajas Guna' merujuk kepada sifat-sifat seorang individu yang hanya berfikir tentang diri sendiri kerana lebih mementingkan ego, kemasyhuran, nama dan kuasa. 'Tamas Guna' merujuk kepada kualiti individu yang tidak berhemah dan didorong oleh minat peribadi mereka, serta sanggup untuk mengorbankan orang lain untuk mencapai cita-cita sendiri. Berdasarkan tiga gunas yang dibincangkan, didapati bahawa definisi komunikasi kepimpinan kaum India adalah konsisten dengan 'Sattva Guna' yang menekankan kepada sifat pemimpin sebagai seorang individu yang memiliki sifat-sifat positif, tidak pentingkan diri sendiri, bertugas untuk mencapai matlamat atau visi bersama, dan bekerja untuk kebaikan rakyat. Ciri-ciri 'Sattva' mempamerkan etika seorang pemimpin yang dapat memberi inspirasi dan secara langsung mencipta persepsi positif dalam kalangan pengikutnya. Menurut Kejriwal dan Krishnan (2004), 'Sattva Guna' terbukti dapat memupuk semangat kepimpinan transformasi yang boleh membawa perubahan kepada masyarakat. Pendek kata, komunikasi kepimpinan dapat didefinisikan sebagai proses mempamerkan tingkah laku beretika dan tidak mementingkan diri sendiri, memotivasi para pengikut melalui kemahiran berkomunikasi yang berkesan, dan mengamalkan gaya kepimpinan inklusif yang menggalakkan maklum balas, cadangan dan komen daripada pengikut.

\section{Fungsi Komunikasi Kepimpinan}

Berdasarkan dapatan kajian, fungsi komunikasi kepemimpinan terbahagi kepada dua tema utama iaitu memotivasi dan mewujudkan keyakinan, dan mengenal pasti keperluan serta kehendak pengikut. Berdasarkan sesi temu bual mendalam, informan 20 dan 7 menyatakan bahawa komunikasi kepemimpinan yang berkesan melibatkan kemampuan pemimpin untuk 
memotivasi dan mewujudkan keyakinan dalam kalangan pengikut. Dalam sesi temu bual, informan 20 menjelaskan bahawa:

“... Biasanya, pengikut mencari harapan. Sekiranya seorang pemimpin optimis, dia dapat menanamkan keberanian dan keyakinan dalam kalangan pengikut. Pengikut memerlukan pemimpin untuk membimbing mereka di semua peringkat. Komunikasi kepimpinan penting untuk berkomunikasi dengan pengikut dan menggerakkan mereka. Sebagai contoh, Hitler menggunakan komunikasi kepemimpinannya untuk menanam keyakinan dalam kalangan pengikut untuk bangkit. Oleh itu, beliau menganggap dirinya lebih unggul daripada orang lain. Beliau menggerakkan pengikutnya untuk berperang, sementara Gandhi pula menggunakan komunikasi kepemimpinannya untuk tujuan perdamaian. Komunikasi kepemimpinan adalah proses mempengaruhi pengikut dan bergantung pada kaedah komunikasi..." (R20).

Idea ini turut disokong oleh informan 7 yang mengatakan bahawa cara pemimpin berkomunikasi akan memberi keyakinan kepada masyarakat untuk membangun. Informan 10, 11 dan 19 secara konsisten mendakwa bahawa komunikasi kepemimpinan yang berkesan dapat mengenal pasti kehendak dan keperluan pengikut. Ini terbukti dalam petikan berikut: "... Ini adalah kerana melalui komunikasi kepemimpinan yang berkesan, pemimpin akan memahami keperluan orang..." (R10).

"... Ya, sangat penting, mesejnya mungkin sama; tetapi cara penyampaian dapat membawa perubahan yang berbeza. Kita dapat melihat Mahatma Gandhi yang menggunakan kemahiran komunikasi kepemimpinannya; beliau menekankan tentang 'Ahimsa' yang bukan sesuatu yang baru dalam agama Hindu. Tetapi dia dapat mencetuskan perubahan sosial dan menyatukan rakyat untuk mendapatkan kemerdekaan. Oleh itu, apabila kita menyebut gerakan Ahimsa, orang akan merujuk pada Mahatma Gandhi walaupun konsep perdamaian atau "Ahimsa" merupakan asas agama Hindu dan budaya India ..." (R11).

Informan 19 juga sangat percaya bahawa komunikasi kepemimpinan dapat membantu kita meneroka dan menyelesaikan masalah. Sebagai pekerja sosial, kita memerlukan kemahiran komunikasi yang baik untuk meneroka dan menyelesaikan masalah yang dihadapi pengikut.

Hasil analisis mendapati bahawa terdapat dua fungsi utama komunikasi kepimpinan iaitu mengenal pasti kehendak dan keperluan masyarakat; dan memotivasi dan memberi inspirasi kepada masyarakat. Penyelidikan ini mengenal pasti bahawa kemahiran komunikasi kepimpinan yang berkesan berupaya mengenal pasti kehendak dan keperluan pengikut. Berdasarkan perbincangan dalam bahagian sebelumnya tentang ciri-ciri komunikasi kepimpinan yang berkesan, seorang pemimpin yang memiliki ciri-ciri tersebut berupaya menjalin hubungan erat dengan para pengikutnya. Oleh itu, pemimpin tersebut dapat memahami masalah akar umbi masyarakat atau pengikut. Selain itu, komunikasi kepimpinan berkesan juga membolehkan pemimpin memotivasi dan melahirkan keyakinan dalam kalangan pengikut. Ini dapat dilakukan 
kerana kemahiran komunikasi kepimpinan berkesan dapat memujuk para pengikut ke arah matlamat yang telah telah dirangka oleh pemimpin yang sejajar dengan kehendak dan keperluan pengikut. Maka, pemimpin tersebut akan menerima kepercayaan pengikut untuk terus memimpin mereka.

\section{Ciri-Ciri Komunikasi Kepimpinan Yang Baik}

\begin{tabular}{|l|l|l|}
\hline \multicolumn{1}{|c|}{ 1. Sifat Positif } & \multicolumn{1}{|c|}{ 2. Gaya Kepimpinan } & 3. Cara berkomunikasi \\
\hline $\begin{array}{l}\text { Tidak mementingkan diri } \\
\text { sendiri } \\
\begin{array}{l}\text { Penyelesai Masalah } \\
\text { Beretika }\end{array}\end{array}$ & $\begin{array}{l}\text { Inklusif } \\
\text { Pemikiran Kritikal }\end{array}$ & $\begin{array}{l}\text { Keseimbangan emosi } \\
\text { Menepati janji } \\
\text { Berupaya mengurus dan } \\
\text { mengawal orang ramai }\end{array}$ \\
\hline
\end{tabular}

Rajah 2: Ciri-ciri komunikasi kepimpinan yang baik

Kajian ini mendapati bahawa ciri-ciri komunikasi kepimpinan yang baik terdiri daripada tiga idea utama yang konsisten dengan definisi komunikasi kepimpinan kaum India. Penemuan penyelidikan menunjukkan bahawa orang India menekankan sifat-sifat positif seorang pemimpin, termasuk sifat tidak mementingkan diri, mampu menyelesaikan masalah dan beretika. Seorang pemimpin harus berkomunikasi dengan ikhlas dengan orang ramai dan bekerja tanpa mengharapkan ganjaran. Di samping itu, seorang pemimpin harus dapat menyampaikan idea, visi, dan dasarnya bagi kepentingan orang ramai untuk membangunkan masyarakat dan negara. Jika seorang pemimpin itu sentiasa memelihara kepentingan pengikutnya tanpa mementingkan diri sendiri, maka akan terjalin hubungan positif antara kedua-dua pihak tersebut. Sikap tidak pentingkan diri sendiri menunjukkan bahawa seorang pemimpin mempunyai keupayaan untuk mengenal pasti dan menyelesaikan masalah berkaitan dengan orang ramai. Dapatan kajian ini menjelaskan bahawa seorang pemimpin perlu mengenal pasti masalah dalam masyarakat dan menyelesaikannya dengan sewajarnya. Justeru, kaum India menekankan bahawa seorang pemimpin perlu bersikap jujur dan kepimpinannya harus telus. Ini adalah kerana para informan percaya bahawa pemimpin adalah contoh dan idola. Oleh itu, amatlah penting bagi pemimpin mempamerkan etika yang tinggi. Ketelusan dianggap sebagai komponen etika yang sangat penting oleh masyarakat Hindu kerana komponen etika memberikan ruang kepada para pengikut untuk menilai keperibadian seorang pemimpin. Satu penyelidikan yang dijalankan oleh Kaur dan Sinha (1992) menunjukkan beberapa sifat yang mencerminkan 'Sattva Guna'. Sifat-sifat tersebut adalah ketelusan, semangat tinggi, dan mengejar kemajuan. Oleh itu, penyelidikan ini mendapati unsur ketelusan yang diketengahkan oleh informan adalah selaras dengan 'Sattva Guna' dalam falsafah India. Ini membuktikan bahawa ketelusan seorang pemimpin meningkatkan keyakinan para pengikut terhadap pemimpin.

Komponen kedua ciri komunikasi kepimpinan yang baik ialah gaya kepimpinan. Kajian ini mendapati sifat inklusif atau kepimpinan partisipatif dan pemikiran kritikal sebagai komponen penting kepada komunikasi kepimpinan yang baik. Penyelidikan ini mendapati bahawa seorang pemimpin harus mempraktikkan sifat inklusif di mana beliau harus memenuhi kepentingan 
masyarakat tanpa mengabaikan mana-mana pihak. Sehubungan dengan itu, seorang pemimpin perlu mendapatkan maklum balas, cadangan dan mempraktikan dasar yang sama rata untuk semua golongan masyarakat. Berkenaan sifat inklusif, seorang pemimpin perlu berfikiran kritikal dalam menilai dan membuat keputusan rasional terhadap isu-isu tertentu. Karya Bhagavad-Gita juga telah menekankan pada aspek inklusif sosial. Dalam tulisannya tentang Bhagavad-Gita, Davis (2014) telah menjelaskan tentang Dewa Krishna dilahirkan dalam suku kaum pengembala yang merupakan masyarakat marginal dibandingkan dengan golongan Brahmin dan Kshatriyas. Perkara ini sudah pastinya mencerminkan sifat inklusif sosial.

Komponen ketiga adalah cara berkomunikasi. Pemimpin seharusnya membawa mesej positif melalui proses komunikasi kepimpinannya. Justeru, pemimpin harus selalu menepati janjijanjinya kepada rakyat. Sifat ini penting untuk meraih keyakinan dan kepercayaan rakyat. Selain itu, pemimpin juga perlu mencerminkan kemahiran pentadbirannya dengan menunjukkan kebolehan menguruskan situasi dan isu berkaitan dengan ekonomi, sosial dan politik. Bagi memastikan pentadbiran yang cekap, pemimpin haruslah berpengetahuan dan intelektual. Akhir sekali, kajian ini juga mendapati bahawa ciri-ciri komunikasi kepimpinan yang baik juga melibatkan sifat tidak mementingkan diri sendiri. Ini bermakna pemimpin harus memberi keutamaan kepada komitmen atau tugasnya dan bukannya untuk perkara peribadi. Kawalan emosi dalam berkomunikasi adalah penting untuk menjadi pemimpin yang komited. Sifat-sifat ini adalah penting untuk memastikan seorang pemimpin itu dapat membuat keputusan bijak dan beretika tanpa sebarang prejudis. Sejajar dengan penemuan kajian ini, Bhagavad-Gita telah menekan bahawa seorang pemimpin harus menjalankan tugas yang ditetapkan dan menjadi teladan kepada orang lain (Bhagavad-Gita, 3: 20-21)

Kesimpulannya, berdasarkan perspektif kebudayaan India, ciri-ciri komunikasi kepimpinan yang baik terdiri daripada amalan gaya kepimpinan partisipatif, beretika, dan komunikasi berkesan di mana pemimpin sentiasa memberi motivasi, inspirasi dan mewujudkan keyakinan kepada masyarakat ke arah perubahan sosial. Maka, perbincangan kajian ini didapati relevan dengan nilai agama Hindu yang ditekankan dalam Bhagavad-Gita di mana seorang pemimpin perlu menggalakkan pengikutnya untuk memberikan maklum balas, menjadi komunikator yang berkesan, berani dan berwawasan, dan mengamalkan etika yang baik. Ciri-ciri ini dapat memberi inspirasi dan motivasi kepada pengikut untuk mengubah sikap dan tingkah laku mereka.

Secara ringkasnya, perbincangan dalam dua bahagian sebelum ini juga boleh dikaitkan dengan penjelasan yang diberikan oleh Barrett (2014). Beliau dalam penyelidikannya telah menyatakan bahawa komunikasi kepimpinan merujuk kepada proses menonjolkan etos kepimpinan positif. Dalam bukunya, "Leadership Communication", Barrett (2014) menjelaskan bahawa etos merujuk kepada ciri-ciri pemimpin yang disanjung oleh pengikutnya. Beliau mendapati bahawa ciri-ciri seorang pemimpin yang konsisten dengan pemikiran para pengikut dapat memberi inspirasi dan motivasi kepada para pengikut. Sepertimana yang dibincangkan sebelum ini, seorang pemimpin yang mempunyai etos positif seperti moral dan karisma akan membuatkan pengikutnya mempercayai dan menerima kepimpinannya. Penemuan penyelidikan ini adalah selaras dengan salah satu konsep agama Hindu, Karma-yoga yang dibincangkan dalam Bhagavad-Gita. 
Karma merujuk kepada tindakan yang melibatkan badan, fikiran dan ucapan (Mulla \& Krishnan, 2010). Karma-yoga telah menggariskan tiga idea utama iaitu kewajipan membantu orang lain, keikhlasan dan keharmonian persekitaran. Pada asasnya, Karma-yoga menggalakkan seorang individu untuk memiliki kebijaksanaan dan melaksanakan tugas tanpa mengharapkan ganjaran (Mulla \& Krishnan, 2006). Dalam penyelidikan mereka, Mulla dan Krishnan (2010) mendapati bahawa Karma-yoga mewujudkan pemimpin yang lebih baik dengan meningkatkan 'Sattva Guna'. Selaras dengan idea itu, kajian ini mendapati bahawa budaya India yang unik mempengaruhi persepsi kaum India terhadap komunikasi kepimpinan yang seterusnya membentuk konsep kepimpinan berdasarkan budaya India (agama Hindu). Kesimpulannya, seorang pemimpin yang mempraktikan konsep 'Sattva Guna' akan mementingkan tanggungjawab (Karma-yoga) dan mencerminkan kualiti komunikasi kepimpinan yang positif dan mempengaruhi komuniti untuk pembangunan masyarakat dan negara.

\section{KESIMPULAN}

Ringkasnya, perbincangan dalam tiga bahagian sebelumnya dapat dibandingkan dengan perbincangan Barrett (2014). Barrett (2014) menyatakan bahawa komunikasi kepemimpinan merujuk kepada satu proses menunjukkan etos kepemimpinan yang positif. Barrett (2014) turut menjelaskan bahawa etos merujuk kepada ciri-ciri pemimpin yang terpuji dari sudut pandangan pengikutnya. Didapati bahawa ciri-ciri kepimpinan yang sejajar dengan kehendak para pengikut, akan memberi inspirasi dan motivasi kepada mereka. Didapati bahawa seorang pemimpin yang menunjukkan etos positif seperti karisma dan etika akan menjadikan pengikutnya mempercayai kepemimpinan. Dalam segi falsafah India, dapatan kajian ini didapati menyokong falsafah Karmayoga yang dibincangkan dalam karya klasik, Bhagavad-Gita. Pada dasarnya, Karma-yoga mendorong seseorang untuk memiliki kebijaksanaan dan melakukan tugas tanpa mengharapkan sebarang penghargaan. Dalam penyelidikan mereka, Mulla dan Krishnan (2010) menemukan bahawa Karma-yoga melahirkan pemimpin yang lebih mulia kerana menekankan aspek "sattva guna" yang merujuk kepada bekerja untuk peningkatan atau kepentingan orang lain. Selaras dengan idea tersebut, melalui penyelidikan ini, didapati bahawa budaya dan falsafah India yang unik ini mempengaruhi persepsi orang India terhadap komunikasi kepemimpinan. Kesimpulannya, seorang pemimpin yang memiliki "sattva guna" akan sentiasa fokus pada tugas atau tanggungjawabnya (Karma-yoga) dan mencerminkan sifat komunikasi kepimimpinan positif yang akan mempengaruhi pengikut ke arah perubahan sosial.

Penyelidikan ini telah memberikan bukti yang jelas tentang deskripsi kaum India di bawah komunikasi kepimpinan Mahathir Mohamad. Selain itu, penyelidikan ini juga memberi gambaran tentang konsepsi kaum India terhadap komunikasi kepimpinan. Penyelidikan ini juga menyumbang kepada pengetahuan komunikasi kepimpinan, khususnya dari perspektif budaya (agama) pengikut dalam sebuah kepimpinan yang berbeza budaya. Ini juga membuktikan bahawa budaya pengikut memainkan peranan aktif dalam proses komunikasi kepimpinan, khususnya dalam menentukan ciri-ciri komunikasi kepimpinan. Adalah jelas bahawa budaya (falsafah agama) kaum India mempengaruhi sikap dan tingkah laku mereka terhadap komunikasi kepimpinan untuk perubahan sosial. Kajian ini menjelaskan bahawa masyarakat Hindu melihat Mahathir Mohamad sebagai seorang pemimpin transformasi yang mempamerkan sifat Sattva Guna yang 
telah mempengaruhi mereka terhadap kepimpinannya dan menyumbangkan ke arah perubahan sosial.

\section{BIODATA}

S. Maartandan Suppiah merupakan penolong professor dan ketua Jabatan Perhubungan Awam di Universiti Tunku Abdul Rahman, Perak, Malaysia. Bidang penyelidikan beliau ialah komunikasi kepimpinan dari perspektif agama Hindu dan komunikasi antara budaya. Artikel beliau juga tersiar dalam Journal of Intercultural Communication Research. E-mel: maartandan@utar.edu.my

Mohd Khairie Ahmad merupakan Pensyarah Kanan di Pusat Pengajian Teknologi Multimedia \& Komunikasi, Universiti Utara Malaysia. Beliau juga merupakan Felo di Institute for Management and Business Research (IMBRe) UUM. Bidang penyelidikan beliau merangkumi bidang komunikasi, perubahan sosial, media, komunikasi kepimpinan dan komunikasi pengurusan. Emel: khairie@uum.edu.my

Heran Niruba merupakan pensyarah di Jabatan Komunikasi Massa, UOW Malaysia, Kolej Universiti KDU Penang. Bidang penyelidikan beliau ialah komunikasi dan kewartawanan, penumpuan media dan perwakilan gender dalam media. E-mel: niruba.g@kdupg.edu.my 


\section{RUJUKAN}

Abdul Rahman Embong. (2001). The culture and practice of pluralism in post-independence Malaysia. In R. W. Hefner (Ed.), The politics of multiculturalism (pp. 59-85). Honolulu: University of Hawaii Press. https://doi.org/10.1515/9780824864965-003

Ahmad Atory Hussain. (1997). The leadership factor in administrative reform in Malaysia, with a specific study on the leadership of Dr. Mahathir Mohamad, Prime Minister of Malaysia. Pertanika Journal of Social Science \& Humanities, 5(2), 103-123.

Ayodurai, D., Yahaya, S., \& Zainuddin, S. (2002). Malaysia. In M. Zanko (Ed.), The handbook of HRM policies and practices in Asia Pacific economies (Vol. 1). Cheltenham: Edward Elgar.

Baharuddin, S. A. (2005). Making sense of national unity in Malaysia: 'Break down' versus 'breakout' perspective. Kuala Lumpur: COLLA Research Group.

Barrett, D. J. (2014). Leadership communication (4th ed.). New York: McGraw-Hill Education.

Bass, B. M., \& Stogdill, R. M. (1990). Bass \& Stogdill's handbook of leadership: Theory, research, and managerial applications. New York, NY: Simon and Schuster.

Bass, B. M. (1990). Bass \& Stogdill's handbook of leadership (3rd ed.). New York, NY: Free Press.

Bass, B. M. (1997). Does the transactional-transformational leadership paradigm transcend organizational and national boundaries? American Psychologist, 52(2), 130-139.

Bass, B. M., \& Avolio, B. J. (1994). Improving organizational effectiveness through transformational leadership. Thousand Oaks, CA: Sage Publications.

Bryman, A., Collinson, D., Grint, K., Jackson, B., \& Uhl-Bien, M. (2011). The SAGE handbook of leadership. Los Angeles: SAGE Publications.

Boatwright, K. J., \& Forrest, L. (2000). Leadership preferences: The influence of gender and needs for connection on workers' ideal preferences for leadership behaviors. The Journal of Leadership Studies, 7(2), 18-34. https://doi.org/10.1177/107179190000700202

Burns, J. M. (1978). Leadership. New York: Harper \& Row.

Cundiff, N. L., \& Komarraju, M. (2008). Gender differences in ethnocultural empathy and attitudes toward men and women in authority. Journal of Leadership \& Organizational Studies, 15(1), 5-15. https://doi.org/10.1177/1548051808318000

Chemers, M. M., \& Ayman, R. (1993). Leadership theory and research: Perspectives and directions. San Diego: Academic Press.

Colaizzi, P. (1978). Psychological research as the phenomenologist views it. In Valle R. S, \& King, M. (Eds.), Existential phenomenological alternatives for psychology. New York: Oxford University Press.

Chinmayanda, S. (2003). The Holy Geeta. Mumbai: Central Chinmaya Mission Trust.

Czech, K., \& Forward, G. L. (2010). Leader communication: Faculty perceptions of the department chair. Communication Quarterly, 58(4), 431-457. https://doi.org/10.1080/01463373.2010.525158

Dansereau, F., Yammarino, F. J., \& Markham, S. E. (1995). Leadership: The multiple-level approaches. The Leadership Quarterly, 6(2), 97-109.

Dahlia, Z. (2008). Cultural dimension among Malaysian employees. International Journal of Economics and Management, 2(2), 479-490.

Davis, R. H. (2014). The "Bhagavad-Gita": A biography. NJ: Princeton University Press.

Engardio, P., \& McGregor, J. (2006, October 30). Karma capitalism. Business Week. 
Ergeneli, A., Gohar, R. \& Temirbekova, Z. (2007). Transformational leadership: Its relationship to culture value dimensions. International Journal of Intercultural Relations, 31(6), 703 - 724. https://doi.org/10.1016/j.ijintrel.2007.07.003

Easwaran, E. (1985). The Bhagavad Gita. Tomales, CA: Nilgiri Press.

Jung, D., \& Avolio, B. (1999). Effects of leadership style and followers' cultural values on performance under different task structure conditions. Academy of Management Journal, 42, 208-218. https://doi.org/10.2307/257093

Gardenswartz, L., Rowe, A., Digh, P., \& Bennett, B. (2003). The global diversity desk reference: Managing an international workforce. Somerset, NJ: Wiley Publishers.

Graen, G. B. (2006). In the eye of the beholder: Cross-cultural lesson in leadership from project GLOBE: A response viewed from the third culture bonding (TCB) model of cross-cultural leadership. The Academy of Management Perspective, 20(4), 95-101.

Gudykunst, W. B., \& Nishida, T. (2001). Anxiety, uncertainty, and perceived effectiveness of communication across relationships and cultures. International Journal of Intercultural Relations, 25(1), 55-71.

Guan, Y. S. (2005). Managing sensitivities: Religious pluralism, civil society and inter-faith relations in Malaysia. The Round Table, 94(382), 629-640. https://doi.org/0.1080/00358530500303700

Hee, C. (2007). A holistic approach to business management: Perspectives from the Bhagavadgita. Singapore Management Review, 29(1), 73-84.

Hunt, J. G., Boal, K. B., \& Sorensen, R. L. (1990). Top management leadership: Inside the black box. The Leadership Quarterly, 1, 41-65.

House, R., \& Aditya, R. (1997). The social scientific study of leadership: Quo vadis? Journal of Management, 23(3), 409-474.

Hofstede, G. (1980). Motivation, leadership, and organization: Do American theories apply abroad?. Organizational Dynamics, 9(1), 42-63. https://doi.org/10.1016/00902616(80)90013-3

Hofstede, G. (1991). Empirical models of cultural differences. Lisse, the Netherlands: Swets \& Zeitlinger.

Hofstede, G. (2001). Culture's consequences: Comparing values, behaviors, institutions, and organizations across cultures. Thousand Oaks, CA: Sage.

Hofstede, G., \& Minkov, M. (2010). Long-versus short-term orientation: New perspective. Asia Pacific Business Review, 16(4), 493-504.

Kanungo, R. N., \& Misra, S. (2004). Motivation, leadership, and human performance. In J. Pandey (Ed.), Psychology in India revisited: Developments in the discipline (Vol 3, pp. 309-341). New Delhi: Sage Publications.

Kennedy, J. C. (2002). Leadership in Malaysia: Traditional values, international outlook. Academy of Management Executive, 16(3), 15-25.

Kejriwal, A., \& Krishnan, V. R. (2004). The impact of Vedic worldview and Gunas on transformational leadership. Vikalpa, 29(1), 29-40.

Kellett, J. B., Humphrey, R. H., \& Sleeth, R. G. (2002). Empathy and complex task performance: two routes to leadership. The Leadership Quarterly, 13(5), 523-544. https://doi.org/10.1016/S1048- 9843(02)00142-X 
Krishnan, V. R. (2002). Transformational leadership and value system congruence. International Journal of Value-Based Management, 15(1), 19-33.

Krishnan, V. R. (2001). Can the Indian worldview facilitate the emergence of transformational leaders? Management and Labour Studies, 26(4), 237-244.

Leslie, J. B., \& Van Velsor, E. (1998). A cross national comparison of effective leadership and teamwork toward a specific global workforce. North Carolina: Center for creative leadership.

Lu, X. A. (2003). Reflections on communication, education, scholarship, and life. US: iUniverse.

Lynn-Sze, J. C., Yusof, N., \& Ahmad, M. K. (2014). The relevance of Confucian values to Leadership communication. Jurnal Komunikasi: Malaysian Journal of Communication, 30, 129-144.

Lynn-Sze, J. C., \& Ahmad, M. K. (2017). Confucian value-based leadership communication: A study on Tun Dr. Mahathir Mohamad. Jurnal Komunikasi: Malaysian Journal of Communication, 33(3), 140-156.

Markus, H. R., \& Kitayama, S. (1991). Culture and the self: Implications for cognition, emotion, and motivation. Psychological Review, 224-253.

Mehta, J. M. (2012). Vedic wisdom: Selected verses from The Vedas for material gain and spiritual happiness. New Delhi: V \& S Publishers. ISBN: 978-938-13840-8-4

Melendez, S. E. (1996). An "outsider's" view of leadership. In F. Hesselbein, M. Goldsmith \& R. Beckhard (Eds.), The leader of the future (pp. 293-302). San Fransisco: Jossey-Bass Publishers.

Mohd. Yusoff, Z. H., Roselina, A. S., \& Syed Azizi, W. (2002). Leadership style preferences of Malaysian managers. Malaysian Management Review, 37(1).

Mulla, Z. R., \& Krishnan, V. R. (2010). Do Karma-Yogis make better leaders? Exploring the relationship between the leader's Karma-Yoga and transformational leadership. Journal of Human Values, 15(2), 167-183.

Mulla, Z. R., \& Krishnan, V. R. (2006, December). Karma-yoga: Construct validation using value systems and emotional intelligence. Paper presented at the first international conference of Yale-Great Lakes Center for Management Research on Global Mindset-Indian Roots, Chennai, India.

Muniapan, B. (2006, December). Can the Bhagavad-Gita be used as a manual for management development of Indian managers worldwide?. Paper presented at the 5th Asia Academy of Management Conference, Asian Management: Convergence and Divergence, Tokyo, Japan (pp. 19-21). December, 2006. Retrieved from https://www.researchgate.net/publication/260518340_Muniapan_B_2006_Can_the_B hagavad-

Gita_be_used_as_a_Manual_for_Management_Development_of_Indian_Managers_W orldwide5th_Asia_Academy_of_Management_Conference_Asian_Management_Conver gence_and_Divergence_T

Muniapan, B. (2007). Transformational leadership style demonstrated by Sri Rama in Valmiki Ramayana. International Journal of Indian Culture and Business Management, 1(1), 104115. 
Panda, A., \& Gupta, R. K. (2007). Call for developing indigenous organizational theories in India: Setting agenda for future. International Journal of Indian Culture and Business Management, 1(1/2), 205-243.

Patton, M. Q. (2002). Qualitative research and evaluation methods (3rd ed.). Thousand Oaks, CA: Sage.

Paulienè, R. (2012). Transforming leadership styles and knowledge sharing in a multicultural context. Business, Management and Education, 10(1), 91-109. https://doi.org/10.3846/bme.2012.08

Saad, S. (2012). Re-building the concept of nation building in Malaysia. Asian Social Science, 8(4), 115-123. https://doi.org/10.5539/ass.v8n4p115

Schein, E. H. (1985). Organizational culture and leadership. San Francisco, CA: Jossey-Bass.

Singh, N., \& Krishnan, V. R. (2007). Transformational leadership in India: Developing and validating a new scale using Grounded Theory approach. International Journal of Cross Cultural Management, 7(2), 219-236. https://doi.org/10.1177/1470595807079861

Singh, P., \& Bhandarker, A. (1990). Corporate success and transformational leadership. New Delhi: Wiley Eastern.

Sinha, A. K., \& Kaur, P. (1992). Dimension of Guna in organizational setting. Sage Journals, 17(3).

Smith, P. B., \& Peterson, M. F. (2002). Cross-cultural leadership. In M. J. Gannon \& L. K. Newman (Eds.), The Blackwell handbook of cross-cultural management (pp. 217-235). Oxford: Blackwell Publishers Ltd.

Suppiah, S. M., Ahmad, M. K., \& Nirubagunasekaran, H. (2018). Mahathir's leadership communication: Exploring the Indian political and non-governmental organisation experience. Jurnal Komunikasi: Malaysian Journal of Communication, 34(2), 205-222.

Suppiah, S. M., Ahmad, M. K., Yusof, N., \& Velloo, P. (2019). Mahathir Mohamad's leadership communication attributes for social change: The perspective of Malaysian Hindus. Journal of Intercultural Communication Research, 48(5), 508-532. https://doi.org/10.1080/17475759.2019.1672575

Triandis, H. C., \& Brislin, R. W. (1984). Cross-cultural psychology. American Psychologist, 39, 10061016.

Tichy, N. M., \& DeVanna, M. A. (1990). The transformational leader (2nd ed.). New York: Wiley.

Thomas, J., \& Harden, A. (2008). Methods for the thematic synthesis of qualitative research in systematic reviews. BMC Med Res Meth, 8, 45.

Wibbeke, E. S. (2009). Global business leader. Oxford, UK: Elsevier.

Wain, B. (2012). Malaysian maverick: Mahathir Mohamad in turbulent times. Journal of Social Issues in Southeast Asia, 20(1), 156-160. https://doi.org/10.1355/sj28-1g 